\title{
MODELING OF DYNAMIC SYSTEMS BY METHOD OF BOND GRAPH
}

\author{
Jakovenko V.B. ${ }^{1}$, Mishchuk Y.A. ${ }^{1}$ \\ ${ }^{1}$ Kyiv National University of Construction and Architecture
}

\begin{abstract}
The various technical systems consist of separate parts, which are in a certain way organized as a whole and interact with each other. The interaction is due to the connections of the parts, the external influences and the anticipation of the desired consequences. One of the problems of such interaction is the study of the temporal evolution of the effects of action on objects of different nature. The methodology of the systematic approach to solving management problems is based on two basic principles of modeling and purposefulness. One of the effective methods in which the ideas of component modeling at the lower level (level of energy domains) are implemented is the method of bond graphs. The language of bond graphs allows to build models of dynamic systems in the state space. As a result of the analysis of existing researches and publications, the purpose of research is set, namely: creating dynamic models of technical systems with using the method of the bond graph. In this work, the structural model of control of the harmonic oscillator, which is described by the system of equations in the state space, is presented. In addition to state equations, we obtain observation equations that connect the state with the initial parameter of the system. An oscillatory system with one degree of freedom in which the resistance $R$ is a model for the transformation of mechanical energy into other forms is considered. Also, the principle of constructing a control model in a state of space for a vibrational system with one degree of freedom is considered in the conditions that the system is not perturbed by force, but by speed. The next stage of the complication of the model was the consideration of the case when the support of oscillator has velocity which not equal zero. In accordance with the symbols of the language of the bond graphs, the equations of the system state, transitional structures and observation were compiled. A practical value of the work is the proposed method of building models of control systems in the state space. The originality is that the models have generalizations in case of increasing the dimensionality of the system, as well as when using nonlinear elements of different types. In the language of bond graphs, we can construct a model of a control system in the form of a system of differential equations. Then the search for the output or consequences of the action on the system consists in solving the system of differential equations with a determine control, or action $u(t)$, substituting the found state $x(t)$ into the observation equation and determining $y(t)$.
\end{abstract}

Key words: system simulation, connection graphs, vibrating machines, dynamics of vibration systems.

\section{Introduction}

Modeling plays an important role in designing machines and processes. The exact mathematical description of various systems makes the process of designing machines fast and flexible [1]. Most mathematical models of systems contain elements of different physical nature (electrical, mechanical, hydraulic, pneumatic), which complicates their description [2]. However, the exact modeling of such systems is necessary in the design of energy-efficient machines [3].

\section{Analysis of research and publications}

There is a large number of systems simulation methods. One of the effective methods for obtaining models of technical systems is the method of functionally completed elements [4]. It is based on the distribution of typical elements of a technical object, completed in a construc- tive manner and designed to perform certain functions: engine, spool, amplifier, etc. [5]. Its essence is that in the system there are stand out elementary material elements that are considered as carriers of certain physical properties in terms of generating, accumulation, transfer and transformation of energy. They are called energy domains [6]. However, we need, at a minimum, models of energy sources and converters of energy flow parameters. In sum, such a set can be considered as a structural basis of the lower level [7].

Another effective method in which the ideas of component modeling at the lower level (level of energy domains) are implemented is the bond graph [8]. One of the directions of the development of the theory of bond graphs is given in the source [9]. This direction is represented by a method that generates bond graphs of the Lagrange function. He gives the right but complex 
link structures. Later this method was improved. As a result, he began to provide the correct structure of the bond graphs, but used complex formulas using inertial terms for the modules of the transformer and the gyrator.

In another work, we investigate the application of the Lagrangian bond graphs with the discrete finite element scheme for simulating a wide range of problems of the dynamics of a solid continuous environment [10].

\section{Identification of previously unsettled parts of the general problem}

The modern theory of management is based on the understanding of space and state. For dynamic systems of mechanics, the state is determined by a pair of variables: coordinate $\mathrm{x}$ and speed $\dot{\mathrm{x}}$, or displacement $\mathrm{q}$ and impulse $\mathrm{p}$, which form the so-called state space or phase space. In control systems, not only mechanical but also other methods of energy conversion are used. Almost always these transformations are carried out on one object. Due to these circumstances, the notion of a state requires the expansion and use of such a set of variables that its elements have been universally adapted to application in various cases. One of the methods by which the simulation of such systems is carried out is the bond graph. This method belongs to a group of topological methods. It allows on a single methodological basis to model objects containing elements of different physical type. One of the problems of dissemination of the method is still limited scope of its application for the expansion of which it is necessary to find an appropriate interpretation of the general definitions of the method in the corresponding subject area. The bond graph is promising for automated modeling, as a means for forming models of components of complex objects. However, in the field of machinery for the production of building materials, it has not yet become widespread.

Statement of assignment and methods of its solving. Creating dynamic models of technical systems with using the method of the bond graph.

\section{Study results and their discussion}

The language of the bond graphs allows us to construct models of dynamic systems in the state space. Considering the harmonic oscillator, which is governed by the influence of the external force e ( $t$ ), at the exit there is a displacement $\mathrm{q}$, or velocity $\mathrm{f}$.

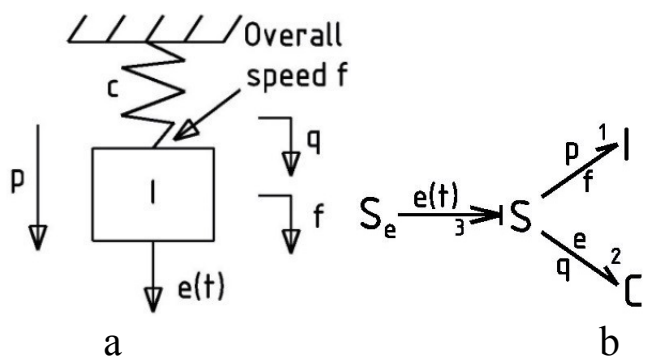

Figure 1. Harmonic oscillator a - physical model; $b$ - bond graph

For the bond graph presented in fig. 1, b the following dependencies are fulfilled.

$$
\begin{gathered}
f_{1}=f_{2}=f_{3} ; \dot{q}=I^{-1} p ; \\
e_{3}=e_{1}+e_{2} ; \quad e=\dot{p}+C^{-1} q .
\end{gathered}
$$

The structural model of control of the harmonic oscillator is presented in Fig. 2.

The system equations of structural model is shown in Fig. 2 as follows:

$$
\left\{\begin{array}{l}
\dot{p}=-C^{-1} q+e(t) \\
\dot{q}=I^{-1} p .
\end{array}\right.
$$

or in curtailed form

$$
I \ddot{q}+C^{-1} q=e(t) .
$$

The system of equations (2) is transformed into a matrix form in the state space. Equation of states:

$$
\begin{aligned}
& {\left[\begin{array}{c}
\dot{\mathrm{p}} \\
\dot{\mathrm{q}}
\end{array}\right]=\left[\begin{array}{cc}
0 & -\mathrm{C}^{-1} \\
\mathrm{I}^{-1} & 0
\end{array}\right]\left[\begin{array}{l}
\mathrm{p} \\
\mathrm{q}
\end{array}\right]+\left[\begin{array}{l}
1 \\
0
\end{array}\right] \mathrm{e}(\mathrm{t}) \quad \text { or } \quad(4)} \\
& \dot{\mathrm{x}}=\mathrm{Ax}+\mathrm{Bu} . \\
& \text { In the formula }(4) \mathrm{A}=\left[\begin{array}{cc}
0 & -\mathrm{C}^{-1} \\
\mathrm{I}^{-1} & 0
\end{array}\right], \\
& \quad \mathrm{B}=\left[\begin{array}{l}
1 \\
0
\end{array}\right] ; \quad \mathrm{x}=\left[\begin{array}{l}
\mathrm{p} \\
\mathrm{q}
\end{array}\right]-\text { state of the state; } \\
& u(t)=e(t)-\text { control. }
\end{aligned}
$$

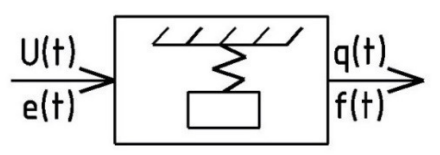

Figure 2. Structural model of control of the harmonic oscillator 
In addition to the state equations, one must obtain the observation equation in the form $\mathrm{y}=\mathrm{Cx}+\mathrm{Du}$, which binds the state to the desired output parameter of the system. To find these equations, you need to specify which parameter is the output of the system. In the case under consideration, this may be the displacement of mass I from the equilibrium position $\mathrm{q}$ or velocity $f$. Assuming that the state vector is $x=\left[\begin{array}{l}p \\ q\end{array}\right]$ known, we obtain the observation equation: displacement:

$$
y=q, y=\left[\begin{array}{ll}
0 & 1
\end{array}\right] x ; y=\left[\begin{array}{ll}
0 & 1
\end{array}\right]\left[\begin{array}{l}
p \\
q
\end{array}\right] ;
$$

velocity:

State:

Transitional structures:

$$
y=f, \mathrm{y}=\left[\begin{array}{ll}
\mathrm{I}^{-1} & 0
\end{array}\right] \mathrm{x} ; \mathrm{y}=\left[\begin{array}{ll}
\mathrm{I}^{-1} & 0
\end{array}\right]\left[\begin{array}{l}
\mathrm{p} \\
\mathrm{q}
\end{array}\right] .
$$

Thus, in the considered example, the model of the control system in the state space is of the form:

$$
\text { state: } \dot{x}=\left[\begin{array}{lc}
0 & -C^{-1} \\
I^{-1} & 0
\end{array}\right] x+\left[\begin{array}{l}
1 \\
0
\end{array}\right] u ;
$$

observation: $y=\left[\begin{array}{ll}0 & 1\end{array}\right] \mathrm{x}$.

Complex object, supplemented by its resistance $r$, which is a model for converting mechanical energy into other forms, for example, thermal acoustic radiation.

In accordance with the designation of the language of the communication graph (Fig. 3):

$$
\begin{aligned}
& \mathrm{s}: \mid \begin{array}{l}
\mathrm{f}_{1}=\mathrm{f}_{2}=\mathrm{f}_{3} ; \\
\mathrm{e}_{4}=\mathrm{e}_{1}+\mathrm{e}_{5}
\end{array} ; \\
& \mathrm{p}: \mid \begin{array}{l}
\mathrm{e}_{5}=\mathrm{e}_{2}=\mathrm{e}_{3} ; \\
\mathrm{f}_{5}=\mathrm{f}_{2}+\mathrm{f}_{3} ;
\end{array} \\
& \mathrm{e}_{1}=\mathrm{e}_{4}-\mathrm{e}_{5}=\mathrm{e}_{4}-\mathrm{e}_{2}=-\mathrm{C}^{1} \mathrm{q}_{2}+\mathrm{e}_{1} \text {; } \\
& \mathrm{f}_{2}=\mathrm{f}_{5}-\mathrm{f}_{3}=\mathrm{f}_{1}-\mathrm{f}_{3}=\mathrm{I}^{-1} \mathrm{p}_{1}-\mathrm{R}^{-1} \mathrm{e}_{2}= \\
& =\mathrm{I}^{-1} \mathrm{p}_{1}-\mathrm{R}^{-1} \mathrm{C}^{-1} \mathrm{q}_{2} \text {. }
\end{aligned}
$$

Converting equations:

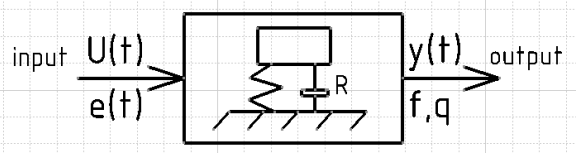

a

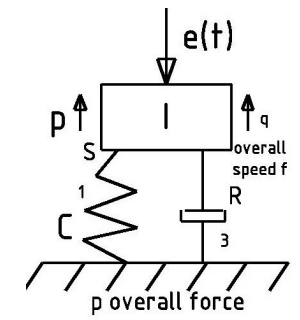

$\mathrm{b}$

Figure 3. Modeling of the element of control system by bond graphs: $a$ - structural model; $b$ - physical model; $\mathrm{c}$ - bond graph

Using equations of state and transitional structures, as well as determination of elements of energy concentrators, we transform the equation in such a way that only the state variables remain and the input control actions then we obtain the equation of state:

$$
\begin{gathered}
\dot{p}_{1}=-C^{-1} q_{2}+e_{4} \\
\dot{q}_{2}=I^{-1} p_{1}-R^{-1} C^{-1} q_{2} \\
{\left[\begin{array}{c}
\dot{p}_{1} \\
\dot{q}_{2}
\end{array}\right]=\left[\begin{array}{ll}
0 & -C^{-1} \\
I^{-1} & R^{-1} C^{-1}
\end{array}\right]\left[\begin{array}{l}
p_{1} \\
q_{2}
\end{array}\right]+\left[\begin{array}{l}
1 \\
0
\end{array}\right] e_{4} .}
\end{gathered}
$$

The system model in the state space has the form

$$
\begin{aligned}
& \text { state: } \dot{\mathrm{x}}=\left[\begin{array}{cc}
0 & -\mathrm{C}^{-1} \\
\mathrm{I}^{-1} & \mathrm{R}^{-1} \mathrm{C}^{-1}
\end{array}\right] x+\left[\begin{array}{l}
1 \\
0
\end{array}\right] \mathrm{u}, \quad \text { or } \\
& \dot{\mathrm{x}}=\mathrm{Ax}+\mathrm{Bu} \text {; }
\end{aligned}
$$

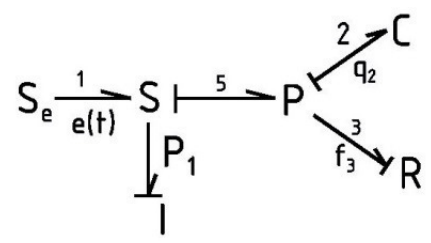

$\mathrm{c}$

observation: $y=\left[\begin{array}{ll}0 & 1\end{array}\right] x$, or $\mathrm{y}=\mathrm{Cx}$.

$$
\text { Here } A=\left[\begin{array}{ll}
0 & -\mathrm{C}^{-1} \\
\mathrm{I}^{-1} & -\mathrm{R}^{-1} \mathrm{C}^{-1}
\end{array}\right] ; \mathrm{B}=\left[\begin{array}{l}
1 \\
0
\end{array}\right] ; \mathrm{x}=\left[\begin{array}{l}
\mathrm{p} \\
\mathrm{q}
\end{array}\right]-
$$

vector of the state; $\mathrm{u}(\mathrm{t})=\mathrm{e}_{4}-$ control; $\mathrm{y}-\mathrm{ob}$ servation.

Let's consider a similar system, but not disturbed by force, but by speed (Fig. 4). 


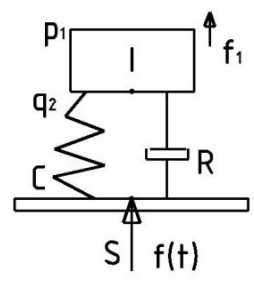

a

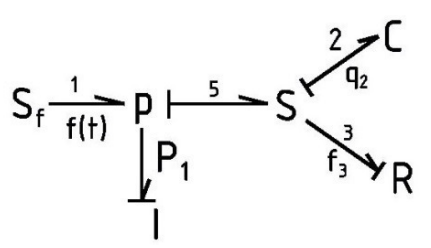

b

$$
\text { State: }\left[\begin{array}{l}
\mathrm{p}_{1} \\
\mathrm{q}_{2}
\end{array}\right] \text {; }
$$

Observation: $\mathrm{q}_{2} ; \mathrm{f}_{1} ; \mathrm{y}=\mathrm{f}_{1}$

Figure 4. Modeling of control system by bond graphs when system disturbed by the speed: a - physical model; $\mathrm{b}$ - bond graph; $\mathrm{c}$ - state and observation equation

Transitional structures:

$$
\begin{array}{cc}
\text { Total } \\
\text { strength }
\end{array} \quad \mathrm{p}:\left|\begin{array}{ll}
\mathrm{e}_{1}=\mathrm{e}_{5} ; \\
\mathrm{f}_{4}=\mathrm{f}_{1}+\mathrm{f}_{5} ;
\end{array} \mathrm{s}:\right| \begin{array}{ll}
\mathrm{f}_{5}=\mathrm{f}_{2}=\mathrm{f}_{3} ; & \dot{\mathrm{p}}_{1}=\mathrm{e}_{1}=\mathrm{e}_{2}+\mathrm{e}_{3}=\mathrm{C}^{-1} \mathrm{q}_{2}+\mathrm{Rf}_{3}= \\
\mathrm{e}_{5}=\mathrm{e}_{2}+\mathrm{e}_{3} ; & =\mathrm{C}^{-1} \mathrm{q}_{2}+\mathrm{Rf}_{4}-\mathrm{RI}^{-1} \mathrm{p}_{1} ; \\
\dot{\mathrm{q}}_{2}=\mathrm{f}_{2}=\mathrm{f}_{5}=\mathrm{f}_{4}-\mathrm{f}_{1}=-\mathrm{I}^{-1} \mathrm{p}_{1}+\mathrm{f}_{4} .
\end{array}
$$

After transformations we have a system of equations:

$$
\begin{gathered}
\dot{\mathrm{p}}_{1}=-\mathrm{RI}^{-1} \mathrm{p}_{1}+\mathrm{C}^{-1} \mathrm{q}_{2}+\mathrm{Rf}_{4} \\
\dot{\mathrm{q}}_{2}=-\mathrm{I}^{-1} \mathrm{p}_{1}+\mathrm{f}_{4} \\
{\left[\begin{array}{c}
\dot{\mathrm{p}}_{1} \\
\dot{\mathrm{q}}_{2}
\end{array}\right]=\left[\begin{array}{cc}
-\mathrm{RI}^{-1} & \mathrm{C}^{-1} \\
-\mathrm{I}^{-1} & 0
\end{array}\right]\left[\begin{array}{l}
\mathrm{p}_{1} \\
\mathrm{q}_{2}
\end{array}\right]+\left[\begin{array}{l}
\mathrm{R} \\
\mathrm{I}
\end{array}\right] \mathrm{f}_{4}}
\end{gathered}
$$

The system model in the state of space has the form

$$
\text { State: } \dot{\mathrm{x}}=\left[\begin{array}{cc}
-\mathrm{RI}^{-1} & \mathrm{C}^{-1} \\
-\mathrm{I}^{-1} & 0
\end{array}\right]\left[\begin{array}{l}
\mathrm{p}_{1} \\
\mathrm{q}_{1}
\end{array}\right]+\left[\begin{array}{l}
\mathrm{R} \\
\mathrm{I}
\end{array}\right] \mathrm{f}_{4} \text {. }
$$

a
Equation of observation of speed $\mathrm{f}_{2}$ to inertia I:

$$
\mathrm{y}=\left[\begin{array}{ll}
\mathrm{I}^{-1} & 0
\end{array}\right] \mathrm{x} .
$$

If you choose the desired vector of observation is not speed, but moving on a spring $\mathrm{q}_{2}$, then the equation of observation will look $\mathrm{y}=\left[\begin{array}{ll}0 & \mathrm{I}\end{array}\right] \mathrm{x}$.

The next stage of the complication of the model is consideration of the case when the speed of the oscillator support is not zero (Fig. 5).

Figure 5. Modeling of control system by bond graphs when the speed of the oscillator support is not zero: a - physical model; $b$ - bond graph

In accordance with the notation of the language of bond graphs:

$$
\begin{aligned}
& \begin{array}{c}
\text { Condition of the system } \\
\text { Overall speed }
\end{array} \\
& \dot{\mathrm{p}}_{1}=\mathrm{e}_{1} \\
& \dot{\mathrm{q}}_{2}=\mathrm{f}_{2}
\end{aligned} ; \quad \mathrm{s}:\left|\begin{array}{l}
\mathrm{f}_{1}=\mathrm{f}_{4}=\mathrm{f}_{6} \\
\mathrm{e}_{1}=\mathrm{e}_{4}+\mathrm{e}_{6}
\end{array} ; \quad \mathrm{p}:\right| \begin{aligned}
& \text { Total strength } \\
& \mathrm{e}_{6}=\mathrm{e}_{5}=\mathrm{e}_{7} \\
& \mathrm{f}_{5}=\mathrm{f}_{6}+\mathrm{f}_{7}
\end{aligned} ; \quad \mathrm{s}: \mid \begin{aligned}
& \mathrm{f}_{7}=\mathrm{f}_{2}=\mathrm{f}_{3} \\
& \mathrm{e}_{7}=\mathrm{e}_{2}+\mathrm{e}_{3}
\end{aligned} .
$$

Observation $\mathrm{y}=\mathrm{q}_{2}$.

The transformation is to find the expression for $\mathrm{e}_{1}$ and $\mathrm{f}_{2}$ through the state variables $\mathrm{p}_{1}, \mathrm{q}_{2}$ or $\mathrm{f}_{1}, \mathrm{e}_{2}$ that is, in the equations must remain state variables and input functions $e_{4}$ and $f_{5}$. The rule of signs - input in s, $\mathrm{p}^{+}$, output - :

$$
\begin{aligned}
& \dot{p}_{1}=e_{1}=e_{4}+e_{5}=e_{4}+e_{7}=e_{4}+e_{2}+e_{3} \\
& =e_{4}+C^{-1} q_{2}+R f_{3}=e_{4}+C^{-1} q_{2}+R f_{7} .
\end{aligned}
$$




$$
\begin{aligned}
& \quad R \mathrm{f}_{7}=R\left(f_{5}-f_{6}\right)=R f_{5}-R f_{6}= \\
& =R f_{5}-R f_{1}=R f_{5}-R I^{-1} p_{1} ; \\
& \dot{q}_{2}=f_{2}=f_{7}=f_{5}-f_{6}=f_{5}-f_{1}= \\
& =f_{5}-I^{-1} p_{1} .
\end{aligned}
$$

Then the equations of state have the form:

$$
\begin{gathered}
\dot{\mathrm{p}}_{1}=-R I^{-1} p_{1}+C^{-1} q_{2}+e_{4}+R f_{5} ; \\
\dot{\mathrm{q}}_{2}=-\dot{I}^{-1} p_{1}+f_{5} \\
{\left[\begin{array}{c}
\dot{\mathrm{p}}_{1} \\
\dot{\mathrm{q}}_{2}
\end{array}\right]=\left[\begin{array}{cc}
-\mathrm{RI}^{-1} & \mathrm{C}^{-1} \\
-\mathrm{I}^{-1} & 0
\end{array}\right]\left[\begin{array}{l}
\mathrm{p}_{1} \\
\mathrm{q}_{2}
\end{array}\right]+\left[\begin{array}{ll}
1 & \mathrm{R} \\
0 & 1
\end{array}\right]\left[\begin{array}{c}
\mathrm{e}_{4} \\
\mathrm{f}_{5}
\end{array}\right] .}
\end{gathered}
$$
look:

Ultimately, the equation of the system will state:

$$
\dot{x}=\left[\begin{array}{cc}
-R^{-1} & C^{-1} \\
-I^{-1} & 0
\end{array}\right] x+\left[\begin{array}{cc}
1 & R \\
0 & 1
\end{array}\right]\left[\begin{array}{l}
e_{4} \\
f_{5}
\end{array}\right] .
$$

If the output in: $f_{5}$ then the equation observation:

$$
y=\left[\begin{array}{ll}
0 & 1
\end{array}\right] \mathrm{x} ; \begin{gathered}
\mathrm{f}_{5}=\mathrm{f}_{6}+\mathrm{f}_{7}=\mathrm{f}_{1}+\mathrm{f}_{2} \\
\mathrm{f}_{\mathrm{s}}=\mathrm{I}^{-1} \mathrm{p}_{1}+\dot{\mathrm{q}}_{2}
\end{gathered} .
$$

If $y=q_{2}$, then the equation of the observation $y=\left[\begin{array}{ll}0 & 1\end{array}\right] \mathrm{x}$.

\section{Conclusions}

Considered in the work of dynamic systems demonstrate the ability of the language of bond graphs for the construction of simple models of control systems in the state space. These models have a generalization in the event of an increase in the dimension of the system, as well as in the application of nonlinear elements of different types.

On the basis of analysis of the dynamical systems considered in the work it becomes clear that for solving simple problems of control theory: under the well-known control $u(t)$ in the model of the system in the state space to find the desired yield $y(t)$, it is necessary to compile and solve a system of differential equations of state.

In the language of bond graphs, we can construct a model of a control system in the form of a system of differential equations. Then the search for the output or effects of the system is to solve the system of differential equations with a given control, or actions $u(t)$, substitution of the found state $\mathrm{x}(\mathrm{t})$ into the observation equation and determination $\mathrm{y}(\mathrm{t})$.

Thus, the main method of solving this problem is to solve the linear first-order differential equations given in the normal form.

\section{Література}

1. Borutzky. W. Bond graph methodology. Development and analysis of multidisciplinary dynamic system models. XXII. $-2010 .-662 \mathrm{p}$.

2. Воронин А.В. Моделирование мехатронних систем: учебное пособие. - Томск: Томский политехнический университет, 2008. - 137 с.

3. Kinematics and dynamics of multibody systems with imperfect joints: Models and case studies / P. Flores, J. Ambrosio, J.C. Pimenta Claro, Hamid M. Lankarani // Springer. Berlin. - 2008. $-169 \mathrm{p}$.

4. Breedveld P.C. Modeling and simulation of dynamic systems using bond graphs. Encyclopedia of Life Support Systems (EOLSS). Vol. 4, Control systems, robotics and automation, Developed under the Auspices of the UNESCO, Eolss Publishers, Oxford, UK. 2008. $-36 \mathrm{p}$.

5. Darina Hroncová, Patrik Šarga, Alexander Gmiterko. Simulation of Mechanical System with Two Degrees of Freedom with Bond Graphs and MATLAB/Simulink // Procedia engineering 48, Košice, Slovak republic. 2012. - P. 223-232.

6. Яковенко В.Б. Нелинейные задачи динамики механических систем. - Київ: Наукова думка, 1996.

7. Яковенко В.Б. Элементы прикладной теории вибрационных систем. - Київ: Наукова думка, 1992. -219 c.

8. Основы моделирования строительных машин: монография / И.И. Назаренко, В.А. Пенчук, В.И. Сердюк, Л.А. Хмара. - Київ: Леся, 2003. $-163 \mathrm{c}$.

9. Robert Thomas McBride. System analysis through bond graph modeling, dissertation for the degree of doctor of philosophy/ Robert Thomas McBride // The university of Arizona. 2005. $325 \mathrm{p}$.

10. Fahrenthold E.P., Wargo J.D. Lagrangian Bond Graphs for Solid Continuum Dynamics Modeling // Journal of Dynamic Systems, Measurement and Control, Trans. ASME. - 1994. - P. 178-192.

\section{References}

1. Borutzky W. (2010) Bond graph methodology. Development and analysis of multidisciplinary dynamic system models. XXII. $-662 \mathrm{p}$.

2. Voronin A.V. (2008) Modelyrovanye mehatronnyh system [Modeling mechatronic systems] [Tomsk, in Russia].

3. Flores P., Ambrosio J., Pimenta Claro J.C., Hamid M. Lankarani (2008) Kinematics and dynamics of multibody systems with imperfect joints: Models and case studies. Springer. Berlin.

4. Breedveld P.C. (2008) Modeling and simulation of dynamic systems using bond graphs. Encyclope- 
dia of Life Support Systems (EOLSS). Vol. 4, Oxford, UK.

5. Hroncová D., Šarga P., Gmiterko A. (2012) Simulation of Mechanical System with Two Degrees of Freedom with Bond Graphs and MATLAB/Simulink / Procedia engineering 48, Košice, Slovak republic, 223-232 p.

6. Jakovenko V.B. (1996) Nelinejnye zadachi dinamiki mehanicheskih sistem [Nonlinear problems of the dynamics of mechanical systems] (Kyiv) [in Ukraine].

7. Jakovenko V.B. (1992) Jelementy prikladnoj teorii vibracionnyh sistem [Elements of the applied theory of vibration systems] (Kyiv) [in Ukraine].

8. Nazarenko I.I., Penchuk V.A., Serdjuk V.I, Hmara L.A. (2003) Osnovy modelirovanija stroitel'nyh mashin: monograph. [Fundamentals of modeling building machines] (Kyiv) [in Ukraine].

9. Robert Thomas McBride (2005) System analysis through bond graph modeling, dissertation for the degree of doctor of philosophy. The university of Arizona.

10. Fahrenthold E.P., Wargo J.D. (1994) Lagrangian Bond Graphs for Solid Continuum Dynamics Modeling. Journal of Dynamic Systems, Measurement and Control, Trans. ASME. P. 178-192.

Jakovenko Valery ${ }^{1}$, Doctor of Technical Sciences, Professor, tel. +380(050) 572 9049,

vyakoven@gmail.com,

Mishchuk Yevhen ${ }^{1}, \mathrm{PhD}$, tel. +380(063) 978 9023, jmishchuk@gmail.com,

${ }^{1}$ Kyiv National University of Construction and Architecture, Povitroflotsky ave., 31, Kyiv, Ukraine, 03037.

\section{Моделювання динамічних систем методом графів зв'язку}

Анотація. У роботі представлена структурна модель керування гармонічним осцилятором, яка описується системою рівнянь у просторі станів. Крім рівнянь стану, отримані рівняння спостереження, які пов'язують стан з вихідним параметром системи. Розглянута коливальна система з одним ступенем вільності, у якій опір $R \in$ моделлю перетворення механічної енергї̈ 6 інші форми. Також розглянуто принщип побудови моделі керування в просторі стану для коливальної системи з одним ступенем вільності за умов, шчо система збурюється не силою, а швидкістю. Наступним етапом ускладнення моделі був розгляд випадку, коли опора осиилятора має не нульову, а будь-яку іншу швидкість. Відповідно до позначень мови графів зв'язку були складені рівняння стану системи, перехідних структур та спостереження.

Ключові слова: системне моделювання, графи зв'язку, вібраційні машини, динаміка вібращійних систем.
Яковенко Валерій Борисович ${ }^{1}$, д.т.н., професор, +380(050) 572 9049, vyakoven@gmail.com,

Міщук Свген Олександрович ${ }^{1}$, к.т.н., доцент, +380(063) 9789023 ,

jmishchuk@gmail.com,

${ }^{1}$ Київський національний університет

будівництва й архітектури, пр. Повітрофлот-

ський, 31, м. Київ, Україна.

\section{Моделирование динамических систем методом графов связи}

Аннотация. В работе представлена структурная модель управления гармоничным осциллятором, которая описывается системой уравнений в пространстве состояний. Кроме уравнений состояния, получены уравнения наблюдения, которые связывают состояние с исходным параметром системы. Рассмотрена колебательная система с одной степенью свободы, в которой сопротивление R является моделью преобразования механической энергии в другие формы. Также рассмотрены принцип построения модели управления в пространстве состояния для колебательной системы с одной степенью свободы при условии, что система возмущается не силой, а скоростью. Следующим этапом усложнения модели было рассмотрение случая, когда опора осциллятора имеет не нулевую, а любую другую скорость. Согласно с обозначениями языка графов связи были составлены уравнения состояния системы, переходных структур и наблюдения. Практической ценностью в работе является предложенный метод построения моделей систем управления в пространстве состояний. Оригинальность заключается в том, что модели имеют обобщения в случае увеличения размерности системы, а также при использовании нелинейных элементов разных типов. На языке графов связи можно построить модель системы управления в виде системы дифференциальных уравнений. Тогда поиск выхода или последствий воздействия на систему заключается в решении системы дифференциальных уравнений при заданном управлении, или действия $\mathrm{u}(\mathrm{t})$, подстановке найденного состояния $\mathrm{x}(\mathrm{t})$ в уравнение наблюдения и определении $\mathrm{y}(\mathrm{t})$.

Яковенко Валерий Борисович ${ }^{1}$, д.т.н., профессор, +380(050) 572 9049,

vyakoven@gmail.com,

Мищук Евгений Александрович ${ }^{1}$, к.т.н., доцент, +380(063) 978 9023, jmishchuk@gmail.com,

${ }^{1}$ Киевский национальный университет строительства и архитектуры, пр. Воздухофлотский, 31, г. Киев, Украина. 